\title{
Caries risk and preventive home-treatment in pre-school children - An Irene Donuts ellaborative pilot study
}

\author{
\#Anne Agustina Suwargiani*, Riana Wardani*, Fidya Meditia Putri*, Sri Susilawati*, \\ Cucu Zubaedah*, Tadeus Arufan Jasrin** \\ *Department of Community Dentistry Faculty of Dentistry Universitas Padjadjaran, Indonesia \\ **Department of Oral Biology Faculty of Dentistry Universitas Padjadjaran, Indonesia
}

\section{ABSTRACT}

Introduction: Caries risk assessment is an effort performed to determine the causes of dental caries and the caries risk of the children. The purpose of the study was to determine the caries risk of preschool children and the possible preventive home-treatment in reducing the risk. Methods: This research was descriptive with sampling method used was the total sampling technique. Data were collected using the Irene's Donuts caries risk form to determine the caries risk and preventive treatment of the children. Caries risk assessment data was presented in the form of frequency distribution tables. Results: The first-year research resulted as follows: distribution of caries risk frequency based on the interview conducted towards the parents in Ulul Azmi and Amanah Kindergarten, regarding their education, age, children's habits, showed that the highest risk $(88.9 \%)$ in both kindergartens was found in children who still drink milk with bottle bottles until more than four-years-old. The second highest risk amongst Ulul Azmi Kindergarten students (88.9\%) was found in children with daily candy consumption; the highest risk amongst Arroyyan Kindergarten (90\%) was tooth decay which considered not interfering the children's development with the pH level below 6.5. Regarding the treatment choice of the students, the most choices taken amongst Ulul Azmi Kindergarten parents were helping their children brush their teeth at night before bedtime; assuring the children's sufficient water consumption in Amanah Kindergarten parents; assuring the children's vegetable and fruits contained menu in Arroyyan Kindergarten parents. Conclusion: The highest caries risk of pre-school children is tooth decay, with the possible preventive home-treatment, were helping the children to brush their teeth at night before bedtime, assuring the children's sufficient water consumption, and assuring the children's vegetable and fruits contained menu.

Keywords: Caries risk, Irene Donuts, preventive home treatment, pre school children.

p-ISSN: 1979-0201; e-ISSN: 2549-6212; Available from: http://jurnal.unpad.ac.id/pjd/editor/submission/18323

DOI: http://dx.doi.org/10.24198/pjd.vol30no2.18323

Submission: November 23, 2017; Accepted: June 29, 2018; Published online: July 31, 2018

\#Corresponding author: Anne Agustina Suwargiani, Department of Community Dentistry, Faculty of Dentistry, Universitas Padjadjaran, Indonesia

Sekeloa Selatan I, Bandung 40132, Indonesia. Phone: +62 813-2017-1707. E-mail: anne.agustina@fkg.unpad.ac.id 


\section{INTRODUCTION}

Dental caries risk data is still very few and not sufficient for modelling purpose, while the process of determining the caries risk is very necessary for clinical decision making. Risk assessment is useful for fostering the treatment of disease processes, providing an understanding of disease factors, and assisting the prevention for individuals, and also choosing and determining the frequency of individual preventive and restorative treatments and anticipating the further development of dental caries. ${ }^{1}$

DMF-T index of Indonesia is 4.6 with respective values of $\mathrm{D}-\mathrm{T}=1.6 ; \mathrm{M}-\mathrm{T}=2.9$; and $\mathrm{F}-\mathrm{T}$ $=0.08 .^{2}$ DMF-T index of Bandung Regency is also valued 4.6, with respective values of $D-T=2.35$; $M-T=3.95$; and $F-T=0.10$. These results indicated that the DMF-T index in Bandung Regency is almost the same as the Indonesian National DMF-T index. ${ }^{2}$

Effective Medical Demand is the number of people with oral health problems in Indonesia, multiplied by the percentage of the population receiving treatment from medical experts, namely general dentists, dental specialist, and dental nurses, in the children with the age group of 1-4 and 5-9 years old. Effective Medical Demand and the correct habit of toothbrushing are found to be lower in the rural areas than in the urban areas. $^{3}$ Most people brush their teeth every day during their morning or afternoon bathtime. These wrong habits are almost evenly distributed across all age groups in Indonesia. ${ }^{3}$ In West Java, as many as $89.4 \%$ of the population brush their teeth every day during their morning or afternoon bathtime, with only as much as $11.9 \%$ of the population brushes their teeth properly. ${ }^{2}$

The prevalence of oral health problem in West Java populations with the age group of 1-4 years old and $5-9$ years old was $9.4 \%$ and $28.4 \%$ respectively. The rural population has lower value compared to the urban populations. ${ }^{2}$ Caries in early childhood known as the early childhood caries (ECC) is a disease caused by the lifestyle begins since the first tooth eruption. The typical pattern of this caries is the fast spread tooth decay and infecting almost all tooth surfaces. ${ }^{4}$

Every individual has different caries risk profile which is slightly different. Thus, the main principles of the patients' management approach must be applied towards each patient's case, from the diagnostic phase and the planning of dental care treatment must also be applied individually. The developing chairside technology nowadays, such as caries susceptibility tests and caries activity tests, can be used to get the baseline and follow-up data in order to assist the dentists in performing these tasks. ${ }^{5}$ However, the dentist's intuition or 'hunch' has been found in many cases to be a better prognostic indicator as a predictive instrument for dental caries experience ahead of new caries. The caries risk data is accumulated and refined in the population, community, and individual level. The sensitivity and specificity of caries risk assessment modelling will increase the positive predictive ability of the final statistical model algorithm. An online caries predictive tools will be available for public dental practitioners in the not too distant future, to help the dentists to formulate the caries risk profiles accurately. ${ }^{5}$ The manual version of Irene Donuts Caries Risk Form is a form contains risk factors related to the children's behaviour; teeth healthiness; condition or environment of mother and child; knowledge, attitudes, and behaviour of the mother as parents. ${ }^{6}$ The above description has encouraged the researcher to conduct a research with the purpose of determining the caries risk of pre-school children and the possible preventive home-treatment in reducing the risk.

\section{METHODS}

The research was descriptive research with the total sampling technique. Data retrieval was performed by using the Innovative Irene Donuts Caries Risk Form for School Oral Health Program (UKGS), to determine the children's caries risk and preventive suggestions that need to be done. The research procedure was already getting approval by the research ethics committee of the Faculty of Medicine Universitas Padjadjaran with registration number 915 / UN6.C10 / PN / 2017.

The caries risk assessment research data was presented in the form of frequency distribution tables. Caries risk research variables were caries risk factors related to the children behaviour; the children's oral health conditions; maternal and child conditions or environment; knowledge, attitudes and behaviour of the mothers as parents. ${ }^{6}$ 
All of these variables were assessed through the drinking and food intake habits, early signs of caries, the mother's educations, the mother and child ages, and the caregiver and parents' oral health knowledge. The caries risk prevention variables were the oral health maintenance options that can be performed at home by the parents.

The interview was performed to collecting data on the children's caries risk factors such as the children's behaviour, oral health condition, condition or environment of mother and child, and the parenting knowledge, attitudes and behaviour of the mothers, were obtained from the parents while the caries experience was assessed from the examination of the acidity level which was obtained directly from the children. The unit of analysis were parents and their children. The caries risk assessment research data was presented in the form of frequency distribution tables. The research locations were the Ulul 'Azmi Islamic Kindergarten (Raudhatul 'Athfal), Amanah Kindergarten, and Arroyyan Integrated Islamic Kindergarten. The research period was from JuneNovember 2017.

\section{RESULTS}

The results obtained from 3 kindergartens, namely the Ulul 'Azmi Islamic Kindergarten (Raudhatul 'Athfal), Amanah Kindergarten, and Arroyyan Integrated Islamic Kindergarten were presented in Table 1, Table 2, Table 3, Table 4, and Table 5.

\section{DISCUSSION}

Children with soft drink consumption habit more than once a week were found in as much as $24 \%$, $29 \%$, and $65 \%$ of all the samples. The first two amounts showed a relatively smaller percentage compared to the third amount, which was relatively high consumption of soft drinks. The soft drinks consumption habit is now the modern social trend and continues to increase. This condition is shown by the sales of this type of beverage which increased by more than $56 \%$ in the last ten years, and is expected to be increasing $2-3 \%$ annually nowadays. ${ }^{7}$

The high sugar content in sweetened drinks has been associated with the presence of tooth decay. Tooth decay is caused by acids produced mainly from the interaction of certain bacteria with sugar. Bacteria produce acids that considered as the cause of caries, the bacteria themselves do not produce enough acid to demineralise the enamel layer. Therefore, the presence of sugar in sugary foods will increase acid production. The frequency of soft drinks will also increase the periodontal disease risk. It is necessary for parents to modify the unhealthy behaviour of their children from an early age. Furthermore, the application of public policy to reduce consumption of sweetened beverages $^{8}$ will encourage the parents' choices on the above results. Dietary habit also plays an important role. Diets that are relevant to dental caries are mostly related to sugary foods, because sugar is undoubtedly the most important substance that causes dental caries. ${ }^{9}$ Implementation of the

Table 1. Respondent's gender frequency distribution

\begin{tabular}{cc}
\hline & Respondent data (Ulul Azmi Islamic Kindergarten) \\
\hline Male & 33 \\
\hline Female & 12 \\
\hline & Respondent data (Amanah Kindergarten) \\
\hline Male & 13 \\
\hline Female & 24 \\
\hline Respondent data (ArRoyyan Integrated Islamic Kindergarten) \\
\hline Male & 7 \\
\hline Female & 13 \\
\hline
\end{tabular}


Table 2. Frequency distribution of interview results regarding children's habit, education and age of parents at Ulul Azmi Islamic Kindergarten

\begin{tabular}{|c|c|c|c|c|}
\hline \multirow{2}{*}{ Children's habit; Parents' education and age } & \multicolumn{2}{|c|}{$\mathrm{F}$} & \multicolumn{2}{|c|}{$\%$} \\
\hline & Yes & No & Yes & No \\
\hline Your child consumes soft drink more than once a week & 11 & 34 & 24.4 & 75.6 \\
\hline Your child consumes milk more than 4-times a day & 8 & 37 & 17.8 & 82.2 \\
\hline You still bottle-feed your child until more than 4-years-old & 7 & 38 & 15.6 & 84.4 \\
\hline Your child has a daily candy-sucking habit & 7 & 38 & 15.6 & 84.4 \\
\hline Your child has a food-sucking habit & 9 & 36 & 20 & 80 \\
\hline Your child has black stain on the back surface of their teeth & 24 & 21 & 53.3 & 46.7 \\
\hline Your child has white spots on their teeth surface & 16 & 29 & 35.6 & 64.4 \\
\hline \multicolumn{5}{|l|}{ Your child has bacterial acidity $\mathrm{pH}$ below 6.5} \\
\hline Mother's education is equally to a bachelor degree, or below senior high school & 21 & 22 & 46.7 & 48.9 \\
\hline Mother's age above 36-years-old & 23 & 22 & 51.1 & 48.9 \\
\hline You breastfeed your child until more than 1-years-old & 34 & 11 & 75.6 & 24.4 \\
\hline Your child aged above 4-years-old now & 43 & 2 & 95.6 & 4.4 \\
\hline Your child is caregiven by their own family & 41 & 4 & 91.1 & 8.9 \\
\hline Do you agree if tooth decay doesn't interfering the childrent's development? & 11 & 32 & 24.4 & 71.1 \\
\hline Your child is toothbrushing with no help & 30 & 15 & 66.7 & 33.3 \\
\hline Your child has tooth decay & 33 & 9 & 73.3 & 20 \\
\hline
\end{tabular}

Table 3. Frequency distribution of interview results regarding children's habit, education and age of parents at Amanah Kindergarten

\begin{tabular}{|c|c|c|c|c|}
\hline \multirow{2}{*}{ Children's habit; Parents' education and age } & \multicolumn{2}{|c|}{$\mathrm{F}$} & \multicolumn{2}{|c|}{$\%$} \\
\hline & Yes & No & Yes & No \\
\hline Your child consumes soft drink more than once a week & 11 & 26 & 29.7 & 70.3 \\
\hline Your child consumes milk more than 4-times a day & 8 & 29 & 21.6 & 78.4 \\
\hline You still bottle-feed your child until more than 4-years-old & 5 & 32 & 13.5 & 86.5 \\
\hline Your child has a daily candy-sucking habit & 18 & 19 & 48.6 & 51.4 \\
\hline Your child has a food-sucking habit & 9 & 28 & 24.3 & 75.7 \\
\hline Your child has black stain on the back surface of their teeth & 22 & 15 & 59.5 & 40.5 \\
\hline Your child has white spots on their teeth surface & 10 & 27 & 27.0 & 73.0 \\
\hline Your child has bacterial acidity $\mathrm{pH}$ below 6.5 & 1 & 36 & 2.7 & 97.3 \\
\hline Mother's education is equally to a bachelor degree, or below senior high school & 12 & 25 & 32.4 & 67.6 \\
\hline Mother's age above 36-years-old & 15 & 22 & 40.5 & 59.5 \\
\hline You breastfeed your child until more than 1 -years-old & 26 & 11 & 70.3 & 29.7 \\
\hline Your child aged above 4-years-old now & 34 & 3 & 91.9 & 8.1 \\
\hline Your child is caregiven by their own family & 34 & 3 & 91.9 & 8.1 \\
\hline Do you agree if tooth decay doesn't interfering the childrent's development? & 9 & 28 & 24.3 & 75.7 \\
\hline
\end{tabular}

\begin{tabular}{|c|c|c|c|c|}
\hline Your child is toothbrushing with no help & 30 & 7 & 81.1 & 18.9 \\
\hline Your child has tooth decay & 28 & 9 & 75.7 & 24.3 \\
\hline
\end{tabular}


Table 4. Frequency distribution of interview results regarding children's habit, education and age of parents at ArRoyyan Integrated Islamic Kindergarten

\begin{tabular}{|c|c|c|c|c|}
\hline \multirow{2}{*}{ Children's habit; Parents' education and age } & \multicolumn{2}{|c|}{$\mathrm{F}$} & \multicolumn{2}{|c|}{$\%$} \\
\hline & Yes & No & Yes & No \\
\hline Your child consumes soft drink more than once a week & 13 & 7 & 65.0 & 35.0 \\
\hline Your child consumes milk more than 4-times a day & 7 & 13 & 35.0 & 65.0 \\
\hline You still bottle-feed your child until more than 4-years-old & 5 & 15 & 25.0 & 75.0 \\
\hline Your child has a daily candy-sucking habit & 12 & 8 & 60.0 & 40.0 \\
\hline Your child has a food-sucking habit & 10 & 10 & 50.0 & 50.0 \\
\hline Your child has black stain on the back surface of their teeth & 14 & 6 & 70.0 & 30.0 \\
\hline Your child has white spots on their teeth surface & 7 & 13 & 35.0 & 65.0 \\
\hline Your child has bacterial acidity pH below 6.5 & 2 & 18 & 10.0 & 90.0 \\
\hline Mother's education is equally to a bachelor degree, or below senior high school & 13 & 7 & 65.0 & 35.0 \\
\hline Mother's age above 36-years-old & 7 & 13 & 35.0 & 65.0 \\
\hline You breastfeed your child until more than 1-years-old & 10 & 10 & 50.0 & 50.0 \\
\hline Your child aged above 4-years-old now & 20 & 0 & 100.0 & 0.0 \\
\hline Your child is caregiven by their own family & 15 & 5 & 75.0 & 25.0 \\
\hline Do you agree if tooth decay doesn't interfering the childrent's development? & 2 & 18 & 10.0 & 90.0 \\
\hline Your child is toothbrushing with no help & 15 & 5 & 75.0 & 25.0 \\
\hline Your child has tooth decay & 15 & 5 & 75.0 & 25.0 \\
\hline
\end{tabular}

Table 5. Frequency distribution of home-treatment choice of parents at all kindergartens

\begin{tabular}{|c|c|c|c|c|c|c|}
\hline \multirow[t]{2}{*}{ Preventive home-treatment choices } & \multicolumn{2}{|c|}{$\begin{array}{c}\text { Ulul Azmi } \\
\text { Islamic Kindergarten }\end{array}$} & \multicolumn{2}{|c|}{$\begin{array}{c}\text { Amanah } \\
\text { Kindergarten }\end{array}$} & \multicolumn{2}{|c|}{$\begin{array}{c}\text { ArRoyyan } \\
\text { Integrated Islamic } \\
\text { Kindergarten }\end{array}$} \\
\hline & $\mathrm{F}$ & $\%$ & $\mathrm{~F}$ & $\%$ & $\mathrm{~F}$ & $\%$ \\
\hline $\begin{array}{l}\text { Limits soft drink consumption for maximum once } \\
\text { a week }\end{array}$ & 24 & 53.3 & 19 & 51.4 & 15 & 75.0 \\
\hline $\begin{array}{l}\text { Rinsing mouth adter drinking milk, and avoid any } \\
\text { milk consumption in the midnight }\end{array}$ & 32 & 71.1 & 27 & 73.0 & 17 & 85.0 \\
\hline $\begin{array}{l}\text { Assuring your children to drink milk and juice with } \\
\text { cup/glass }\end{array}$ & 27 & 60 & 24 & 64.9 & 17 & 85.0 \\
\hline $\begin{array}{l}\text { Changing candy consumption with playing } \\
\text { activities }\end{array}$ & 28 & 62.2 & 25 & 67.6 & 16 & 80.0 \\
\hline Attempting to reduce food-sucking & 25 & 55.6 & 19 & 51.4 & 13 & 65.0 \\
\hline Visiting dentist to cover the children's teeth & 6 & 13.3 & 4 & 10.8 & 4 & 20.0 \\
\hline $\begin{array}{l}\text { Smearing CPP-ACP (vitamins for teeth) twice a } \\
\text { day }\end{array}$ & 2 & 4.4 & 3 & 8.1 & 1 & 5.0 \\
\hline $\begin{array}{l}\text { Assuring the children's sufficient water } \\
\text { consumption }\end{array}$ & 36 & 80 & 30 & 81.1 & 15 & 75.0 \\
\hline $\begin{array}{l}\text { Helping the children to brush their teeth at night } \\
\text { before bedtime }\end{array}$ & 40 & 88.9 & 26 & 70.3 & 16 & 80.0 \\
\hline $\begin{array}{l}\text { Helping the children to brush their teeth at night } \\
\text { before bedtime }\end{array}$ & 16 & 35.6 & 23 & 62.2 & 12 & 60.0 \\
\hline $\begin{array}{l}\text { Assuring no cavity on maxillary premolar to } \\
\text { dentists }\end{array}$ & 16 & 35.6 & 14 & 37.8 & 12 & 60.0 \\
\hline
\end{tabular}


Padjadjaran J Dent. 2018; 30(2): 84-91.

\begin{tabular}{lcccccc}
\hline Cleaning tooth eruption area with wet cotton & 15 & 33.3 & 18 & 48.6 & 17 & 85.0 \\
\hline $\begin{array}{l}\text { Helping the children to brush their teeth at night } \\
\text { before bedtime }\end{array}$ & 19 & 42.2 & 18 & 48.6 & 13 & 65.0 \\
\hline $\begin{array}{l}\text { Assuring the children's vegetable and fruits } \\
\text { contained menu }\end{array}$ & 32 & 71.1 & 26 & 70.3 & 18 & 90.0 \\
\hline $\begin{array}{l}\text { Helping the children to brush their teeth at night } \\
\text { before bedtime }\end{array}$ & 15 & 33.3 & 18 & 48.6 & 14 & 70.0 \\
\hline \begin{tabular}{l} 
Filling decayed tooth to the dentists \\
\hline
\end{tabular} & 10 & 22.2 & 4 & 10.8 & 5 & 25.0 \\
\hline
\end{tabular}

public policy to limits the frequency of soft drinks consumption for maximum once a week, such as increasing the taxes on these products, can help prevent the tooth decay and tooth loss. ${ }^{8}$

Children with milk consumption more than four times daily were found in as much as $17.8 \%$, $21.6 \%$, and $35 \%$ respectively. Children who still drink milk with bottle bottles until more than fouryears-old were found in as much as $15.6 \%, 13.5 \%$, and $25 \%$ respectively. These results indicated that this is a habit needs to be stopped. Formula milk causes a decrease in the salivary $\mathrm{pH}$ to become more acidic, makes it more dangerous for the teeth. ${ }^{10}$ Decreasing salivary $\mathrm{pH}$ will lead to the tooth decay and periodontal diseases. ${ }^{11}$

Non-sweetened dairy products, or specific bioactive components from the same source which are proven to be non-cariogenic, have proven to be part of the tooth decay prevention strategy. Thus, milk proteins, such as bovine, human caseins, and lactoferrin, inhibits the initial attachment of cariogenic Streptococcus mutans towards the hydroxyapatite-coated saliva, or ligands carrying purified saliva. In contrast, both cow and human milk coated in hydroxyapatite promote adhesion of nisin lesions and other beta and streptococcal nucleotide cells in-vitro, and also, fatty milkderived peptides help maintain the teeth mineral, as shown in caseino-phosphate B-casein peptides. Observational studies have shown a very promising results, but randomised clinical trials are needed to reveal whether these dairy products can be a complementary treatment of oral health. ${ }^{12}$

Parents with babies must be informed about the risk of baby bottle caries, and the mother must be informed to not adding any food or drink to the baby bottle other than formula milk, breast milk, cow's milk, or water. As soon as possible, the babies should be encouraged to use a cup or glass rather than a baby bottle, and all bottlefeeding should be stopped at the age of 1-yearsold. ${ }^{13}$ Children with food-sucking habit were found in as much as $15.6 \%, 48.6 \%$, and $50 \%$ respectively. These results showed that more than half of the respondents were having the food-sucking habit. Eating carbohydrates more frequent will increase the caries incidence compared to consuming large amounts of carbohydrate in lesser frequency. ${ }^{14}$ Some clinical trials have shown that chewing a sugar-free gum protects the teeth against dental caries. ${ }^{13}$

The black stain on the back teeth of the children were found in as much as $53.3 \%, 59.5 \%$, and $70 \%$ respectively. This result was almost the same as the result of Basic Health Research (Riskesdas) conducted in 2007, which discovered that dental caries in children under five was estimated to have a fairly high prevalence ( \pm $50.0 \%$ ), and at a certain severity, can interfere with the masticatory system. The result of this study also showed that the prevalence of oral health problems in the 1-4-years-old children was reaching $6.9 \%$ with only $27.4 \%$ treated case. ${ }^{2}$

These results indicated the necessity to prevent oral disease through the school oral health program at an earlier level, especially at the preschool level. ${ }^{12}$ The World Health Organization has recommended certain age groups to be examined, specifically the 5-years-old age group, for the primary teeth condition. The dental caries level of this age group changes faster than on the permanent teeth, and the age of 5-years-old is the school-starting age. The analysis of the data from Basic Health Research in 2007 did not describe the oral health status of 5 -years-old children. Dental caries in school-aged children (5-years-old) currently is still not getting adequate attention and treatment. ${ }^{2}$ 
White spots on the children's teeth surfaces were found in $35.6 \%, 27.7 \%$, and $35 \%$ respectively. White patches are an indication of enamel demineralisation that is detected clinically, observed as the white spots with different opacities, as a sign of the beginning of the caries process. Dental caries results in the loss of apatite crystals, calcium, phosphate, and other ions, which eventually causes demineralisation of the tooth substrate. The subsurface porosity caused by demineralisation gives opaque appearance lesions that can be found on the tooth surface. ${ }^{16}$

White spots on the children's tooth surface can be removed with minimal intervention. Minimal intervention is the ideal approach to managing white spots, and should be initiated with remineralisation therapy to restrain the disease process and restore the enamel strength and function. Patient expectations are very important for the decision-making process, because aesthetic concerns must also deal with simultaneously. ${ }^{16}$ Tooth filling needs to be done to prevent the tooth damage severity.

\section{CONCLUSION}

The highest caries risk of pre-school children is tooth decay, with the possible preventive hometreatment, were helping the children to brush their teeth at night before bedtime, assuring the children's sufficient water consumption, and assuring the children's vegetable and fruits contained menu.

\section{REFERENCES}

1. American Academy Of Pediatric Dentistry. Guideline On Caries-Risk Assessment And Management For Infants, Children, And Adolescents. Reference Manual and Clinical Practice Guidelines. Chicago: American Academy Of Pediatric Dentistry; 2014.

2. National Institute of Health Research and Development (NIHRD). Indonesia Basic Health Research (RISKESDAS) 2012-2013. Jakarta: Ministry of Health of the Republic of Indonesia; 2013.

3. National Institute of Health Research and Development (NIHRD). Indonesia Basic Health Research (RISKESDAS) 2008-2009. Jakarta:
Ministry of Health Republic of Indonesia; 2009.

4. Simratvir M, Moghe GA, Thomas AM, Singh N, Chopra S. Evaluation of caries experience in 3-6-year-old children, and dental attitudes amongst the caregivers in the Ludhiana city. J Indian Soc Pedod Prev Dent. 2009; 27(3): 164-9. DOI: 10.4103/0970-4388.57097

5. Hallet KB. The application of caries risk assessment in minimum intervention dentistry. Australian Dent J. 2013; 58 Suppl 1: 26-34. DOI: $10.1111 /$ adj.12047

6. Directorate of Basic Primary Health Effort. School Oral Health Program Guidelines. Jakarta: Directorate of Basic Primary Health Effort of the Ministry of Health of the Republic of Indonesia; 2012.

7. Sofya PA, Rahmayani L, Purnama RRC. Effect of soft drink towards heat cured acrylic resin denture base surface roughness. Padjadjaran J Dent. 2017; 29(1): 58-63. DOI: 10.24198/ pjd.vol29no1.12614

8. López-Gómez SA, Villalobos-Rodelo JJ, Avila-Burgos L, Casanova-Rosado JF, Vallejos-Sánchez AA, Lucas-Rincón SE, et al. Relationship between premature loss of primary teeth with oral hygiene, consumption of soft drinks, dental care, and previous caries experience. Sci Rep. 2016; 6: 21147. DOI: 10.1038/srep21147

9. Gupta P, Gupta N, Pawar AP, Birajdar SS, Natt AS, Sing HP. Role of Sugar and Sugar Substitutes in Dental Caries: A Review. ISRN Dent. 2013; 2013: 519421. DOI: 10.1155/2013/519421

10. Raju AS, Hirehal M, Manjunath PG, Reddy VVS, Natraj CG. The Acidogenic Potential of Different Milk Formulas on Dental Plaque pH. Oral Health Preventive Dent. 2012; 10(3): 22530.

11. Baliga S, Muglikar S, Kale R. Salivary pH: A diagnostic biomarker. J Indian Soc Periodontol. 2013; 17(4): 461-5. DOI: 10.4103/0972124X.118317

12. Johansson I, Lif Holgerson P. Milk and oral health. Nestle Nutr Workshop Ser Pediatr Program. 2011; 67: 55-66. DOI: 10.1159/000325575.

13. Moynihan PJ. Dietary advice in dental practice. Br Dent J. 2002; 193(10): 563-8. DOI: 10.1038/ sj.bdj. 4801628

14. Suratri MAL, Sintawati FX, Andayasari L. 
Knowledge, Attitudes, and Behavior of Parents About Oral and Dental Health among Kindergarden Age Children in Special Region of Yogyakarta Province and Banten Province. Media Litbangkes. 2016; 26(2): 119-26.

15. Touger-Decker R, van Loveren C. Sugars and dental caries. Am J Clin Nutr. 2003; 78(4):
881S-892S. DOI: 10.1093/ajcn/78.4.881S

16. Decisions In Dentisty [homepage on internet]. Santa Ana: Al Shehri A, Kwon SR. 2016. Etiology and Management of White Spot Lesions. [cited 2018 Jun]; [about 7 screens]. Available from: http://decisionsindentistry.com/article/ lesions-0116/ 